\title{
Adenosine in inflammatory joint diseases
}

\author{
E. S. L. Chan • P. Fernandez • B. N. Cronstein
}

Received: 10 February 2006 / Accepted: 20 February 2006 / Published online: 3 January 2007

(C) Springer Science + Business Media B.V. 2007

\begin{abstract}
Inflammatory joint diseases are a group of heterogeneous disorders with a variety of different etiologies and disease manifestations. However, there are features that are common to all of them: first, the recruitment of various inflammatory cell types that are attracted to involved tissues over the course of the disease process. Second, the treatments used in many of these diseases are commonly medications that suppress or alter immune function. The demonstration that adenosine has endogenous anti-inflammatory functions and that some of the most commonly used anti-rheumatic medications exert their therapeutic effects through stimulation of adenosine release suggest an important role for purinergic signaling in inflammatory rheumatic disorders.
\end{abstract}

Key words adenosine - adhesion molecules · cytokines · methotrexate $\cdot \mathrm{P} 1$ receptors $\cdot$ superoxide

Inflammatory joint diseases are a heterogenous group of disorders afflicting not only joint tissues but often multiple organs in the body. While known etiologies differ among the variety of diseases, treatment often involves medications with immuno-modulatory functions. It has been known for a long time that deficiency of adenosine

E. S. L. Chan · P. Fernandez • B. N. Cronstein

Department of Medicine,

Divisions of Clinical Pharmacology and Rheumatology,

New York University School of Medicine,

New York, NY, USA

\section{B. N. Cronstein $(\bowtie)$}

Medicine, Pathology and Pharmacology,

Division of Clinical Pharmacology, NYU School of Medicine,

550 First Ave., NBV16N1,

New York, NY 10016, USA

e-mail: Bruce.Cronstein@nyumc.org deaminase, the principal catabolizing enzyme for adenosine and deoxyadenosine, is associated with immunity dysfunction. Indeed, one-third of patients with autosomal recessive severe combined immunodeficiency exhibit adenosine deaminase deficiency. The disorder is characterized by abnormal development of lymphocytes in the thymus and may affect maturation of $T$ cells as well as that of B cells [1]. This suggests that endogenous adenosine might have an important immunosuppressive role. The immune effects of adenosine deaminase deficiency have been well studied in animal models of this disease. It appears that the toxic effects on $\mathrm{T}$ and $\mathrm{B}$ lymphocytes are related to increased concentrations of 2'-deoxyadenosine, which, through various mechanisms, increase the rate of apoptosis in the developing thymocytes $[2,3]$. With the discovery of the effects of adenosine in modulating the generation of free oxygen radicals in neutrophils, it was clear that the effects of adenosine on the immune system were widespread and not limited to lymphocytes alone [4]. As interest in the antiinflammatory effects of adenosine grew, it became known that the release of adenosine is important in mediating the therapeutic effects of methotrexate, one of the most widely used disease-modifying medications for rheumatoid arthritis. We will explore some of the physiological mechanisms of adenosine and its receptors relevant to the perpetuation as well as treatment of the rheumatic diseases (Fig. 1).

The cellular components of inflammatory joint diseases

Neutrophils

A hallmark of the inflammatory response is the recruitment of inflammatory cells into the site of inflammation. Histological observation of the cell types involved has 
Fig. 1 The effects of adenosine in inflammatory tissue injury

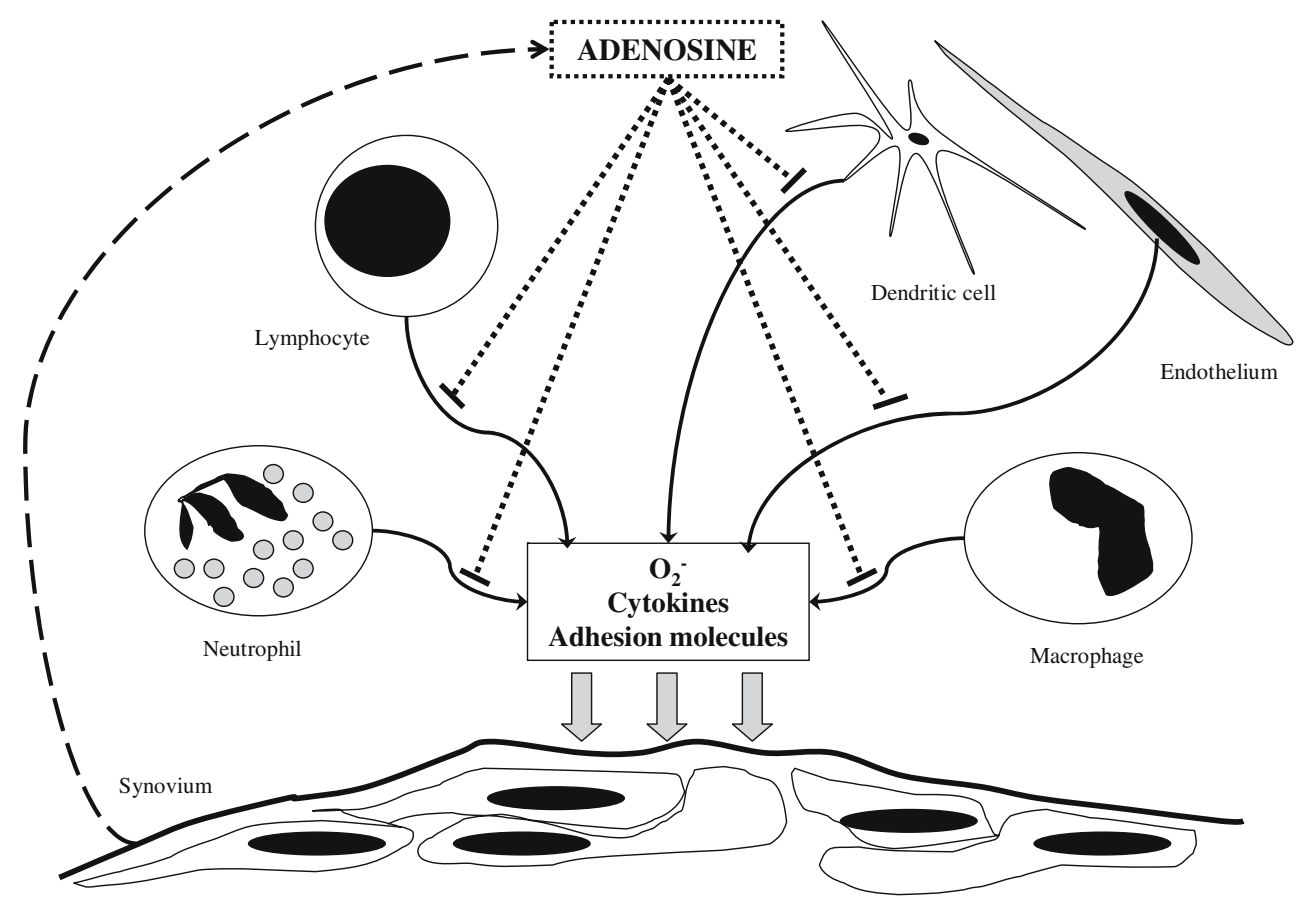

been carried out for as long as the microscope has existed. Early observers have identified the polymorphonuclear neutrophil as an important player in the acute inflammatory response. These cells, when activated, can generate inflammatory damage via various mechanisms. One of the most important of these mechanisms is the generation of free oxygen radicals. In the initiation phase of oxygen radical formation, an NADPH oxidase is assembled within the membrane and the superoxide anion is generated from molecular oxygen in a chain of chemical reactions. There are many known physiological stimulators for the superoxide anion, including the chemo-attractant $\mathrm{N}$-formylmethionyl-leucyl-phenylalanine (FMLP), the complement component $\mathrm{C} 5 \mathrm{a}$, and artificial stimulants such as the calcium ionophore A23187. In 1983 it was shown for the first time that adenosine can dramatically suppress the generation of superoxide anions in neutrophils via interaction with cell surface receptors, which was thought to be the $\mathrm{A}_{2}$ receptor at the time [4-7]. The inhibition of superoxide anion generation was reversed by the addition of adenosine deaminase to the FMLP-stimulated neutrophils in culture. Furthermore, $G_{\alpha \mathrm{s}}$ receptor stimulation led to a rise in intracellular 3', 5' cyclic adenosine monophosphate (cAMP), and inhibition of protein kinase A downstream of this signaling pathway by the inhibitor KT5720 reversed the effects of cAMP analogs but not adenosine receptor agonists on superoxide anion generation in the stimulated neutrophils. These observations are somewhat controversial, as Sullivan et al. have reported that cAMP and protein kinase A mediate the effects of adenosine receptor occupancy in tumor necrosis factor (TNF)-treated neutro- phils [8]. Recent observations suggest that it is possible that cAMP-protein kinase A-mediated effects are more important in regulating function in TNF-treated cells because of the dramatic increase in cAMP generated in TNF-treated cells [9-11]. It was later reported that the receptor in question responsible for these functions was, indeed, the adenosine $A_{2 A}$ receptor $[12,13]$. These findings led to interest in the immuno-modulatory functions of adenosine.

Not only is adenosine important in modulating neutrophilic function, but, much earlier than that in the cascade of inflammatory events, it also influences the recruitment of cells into the inflammatory site by regulating the expression of adhesion molecules [14-16]. Adhesion of the stimulated neutrophil to the endothelium and its chemotaxis are promoted by stimulation of the adenosine $A_{1}$ receptor, whereas stimulation of the $A_{2}$ receptor suppresses neutrophil adhesion and the generation of oxygen radicals [17]. The effects on neutrophil adhesion are relevant to clinical practice, since the expression of adhesion molecules has been shown to be upregulated in circulating blood neutrophils in real-life patients with diseases associated with widespread inflammatory activation such as sepsis [18]. Furthermore, adenosine $A_{2 A}$ receptor activation counteracts the enhancement of adhesion molecule expression in the stimulated neutrophils from these patients. Those findings highlight the opposing roles of the $A_{1}$ and $\mathrm{A}_{2}$ receptors in inflammatory modulation, i.e., proinflammatory and anti-inflammatory, respectively. Transmigration of the neutrophil through the endothelium, as well as the release of vascular endothelial growth factor by neutrophils, are both modulated by the $A_{2 B}$ receptor [19]. 
Macrophages and dendritic cells

Cells of the monocyte-macrophage lineage are significant contributors to tissue damage in the rheumatoid synovium. Their capacity to do so is exemplified by their ability to phagocytose opsonized particles, generate oxidant-induced damage, and produce a whole host of proinflammatory cytokines that augment the inflammatory response. These cytokines can modulate the function and expression of adenosine $\mathrm{A}_{2 \mathrm{~A}}$ as well as $\mathrm{A}_{2 \mathrm{~B}}$ receptors $[9-11,20]$. Adenosine and its analogs can, in turn, regulate production of these cytokines, as well as nitric oxide synthase expression in macrophages [20,21].

Lipopolysaccharide-induced interleukin (IL)-12 production by monocytes and macrophages is an effect mediated by toll-like receptor-4 (TLR4), and IL-12 elicits a strong inflammatory response. Adenosine exerts its anti-inflammatory effects in part by suppressing the production of IL-12 [9, 22-24]. Much like the case with neutrophils, FMLP induces the generation of superoxide anions in monocytes. Adenosine, in micromolar concentrations, suppresses this respiratory burst response to FMLP but not to the induction of phorbol myristate acetate [25]. The Fc gamma receptor serves an important function in mediating phagocytosis in monocytes. Stimulation of the adenosine $\mathrm{A}_{1}$ receptor promotes $\mathrm{Fc}$ gamma receptormediated phagocytosis by monocytes, whereas $\mathrm{A}_{2}$ receptor agonists suppress phagocytosis. Another example of the opposing effects of $A_{1}$ and $A_{2}$ receptors can be seen with multi-nucleated giant cell formation. Multi-nucleated giant cells, formed by the fusion of multiple macrophages, are a distinctive feature of the subcutaneous nodules. These are seen both as a manifestation of rheumatoid arthritis itself and as a consequence of one of its most common drug treatments, methotrexate. Multi-nucleated giant cell formation from stimulated human monocytes is promoted by $\mathrm{A}_{1}$ receptor stimulation, while activation of the $\mathrm{A}_{2}$ receptor has the opposing effect [26].

Dendritic cells are also important players in antigen presentation, and they too express adenosine receptors. Lipopolysaccharide induces maturation of dendritic cells, and, as they mature, the $A_{1}$ and $A_{3}$ receptor message is downregulated, while no change is observed with $\mathrm{A}_{2 \mathrm{~A}}$ receptor mRNA [27]. Following activation of the dendritic cell, $\mathrm{A}_{2 \mathrm{~A}}$ receptor ligation inhibits its production of IL-12, much as occurs in macrophages [24]. Other cytokinemodulating effects exist, to include suppression of tumor necrosis factor- $\alpha$ as well as enhancement of secretion of the anti-inflammatory cytokine, interleukin-10 [28]. These effects are also attributable to the $\mathrm{A}_{2 \mathrm{~A}}$ receptor. Furthermore, dendritic cells that matured in the presence of adenosine were less able to promote the differentiation of CD4-positive naïve $\mathrm{T}$ lymphocytes towards a Th1-pheno- type, and this has great implications in limiting a $\mathrm{T}$ cellinitiated proinflammatory response [28].

\section{Lymphocytes}

The $\mathrm{T}$ lymphocyte remains one of the key cell types responsible for the inflammatory state in the rheumatoid synovium. At low concentrations of extracellular adenosine, inhibition of $\mathrm{T}$ cell receptor-triggered proliferation and induction of interleukin- $2 \alpha$ chain expression has been observed, and these may be important contributing mechanisms for causing peripheral $\mathrm{T}$ cell depletion [29]. These effects are mediated through the adenosine $\mathrm{A}_{2 \mathrm{~A}}$ receptor. Indeed, adenosine acts as a strong suppressant of many known $\mathrm{T}$ cell receptor-triggered effector functions of $\mathrm{T}$ lymphocytes, such as induced FasL expression on cytotoxic $\mathrm{T}$ lymphocytes. While exposure to ligands may be brief, effector functions and cellular changes in cAMP may be more prolonged and contribute to $\mathrm{T}$ cell memory [30]. Much as the response to ligand activation varies among $\mathrm{T}$ lymphocytes, adenosine receptor expression is also cell type-dependent, and lymphokine-producing $\mathrm{T}$ helper cells have been cited to be much more likely to express $A_{2 A}$ receptors [31]. $T$ cell receptor activation is associated with a rapid induction of adenosine $A_{2 A}$ receptor message expression, and $\mathrm{A}_{2 \mathrm{~A}}$ receptor activation profoundly suppresses $\mathrm{T}$ cell receptor-mediated interferon- $\gamma$ production [32]. Thus, adenosine $A_{2 A}$ receptor activation is generally beneficial for the impairment of $\mathrm{T}$ lymphocytetriggered events in the pathogenesis of rheumatic disease.

\section{Endothelial cells}

The vascular endothelium limits the flow of traffic between the vascular lumen and surrounding tissues, and as such, it serves an important function in regulating the influx of inflammatory cells into the site of inflammation. Activation of the endothelium may result from the influence of a vast number of inflammatory mediators, including cytokines such as tumor necrosis factor- $\alpha$ and interleukin- 1 as well as immune components such as immune complexes and complement components. Endothelial permeability is increased by oxidant injury, and the resultant extravasation of fluid normally contained within the vessel lumen can be seen as inflammatory edema. The neutrophil, once activated, is induced to release AMP and adenosine, which augments this barrier function in an in vitro endothelial paracellular permeability model [33]. The endothelium has the intrinsic ability to generate adenosine by dephosphorylation of AMP through the action of 5 '-ectonucleotidase. Passage of Evan's blue dye-labeled albumin across confluent monolayers of human umbilical vein endothelial cells (HUVECs) is hampered in the presence of adenosine, a 
function thought to be mediated by adenosine $A_{1}$ receptors [34]. Others have argued that the function of the endothelial barrier is more closely related to adenosine $A_{2 B}$ receptor activation, since $A_{2 B}$ receptor antagonists effectively reverse ATP-induced changes in endothelial permeability following hypoxic insult [35]. These data demonstrate that adenosine exerts its overall anti-inflammatory function in part by limiting extravasation at the endothelial level. In contrast, adenosine has also been reported to induce apoptosis in endothelial cells, a physiological activity that requires protein tyrosine phosphatase [36]. The outflow of inflammatory cells is similarly suppressed in the presence of adenosine. This occurs as a result of alteration in adhesion molecule expression such as E-selectin and vascular cell adhesion molecule-1 (VCAM-1) in the presence of adenosine [37]. In addition, dose-dependent suppression of the expression of inflammatory cytokines IL- 6 and IL- 8 by stimulated HUVECs has also been observed [37]. Proliferation of endothelial cells is stimulated by the presence of adenosine, and this signals a role for adenosine in the promotion of angiogenesis, since neovascularization in the retina is suppressed by ribozymes that cleave $\mathrm{A}_{2 \mathrm{~B}}$ receptor mRNA $[38,39]$. The proliferative effect is, in part, mediated through induction of the formation of vascular endothelial growth factor [40]. Response to adenosine receptor occupancy varies between cell types, since agonist-induced upregulation of interleukin-8, vascular endothelial growth factor and basic fibroblast growth factor occurs in human microvascular endothelial cells (HMEC-1) but not HUVECs [41]. This effect, attributable to $A_{2 B}$ receptor activation, occurs via $\mathrm{Gq}$ and possibly $\mathrm{G}_{12 / 13}$ coupling. Tissue hypoxia has a modulatory effect on endothelial adenosine receptor expression in favor of an $\mathrm{A}_{2 \mathrm{~B}}$ pro-angiogenic phenotype [42]. The adenosine $\mathrm{A}_{2 \mathrm{~A}}$ receptor also has an important role to play in regulating angiogenesis. $A_{2 \mathrm{~A}}$ receptor stimulation in primary human endothelial cells is known to activate the mitogen-activated protein kinase signaling pathway [43]. Using a murine air pouch model, Montesinos et al. first demonstrated that angiogenesis is inhibited in adenosine $\mathrm{A}_{2 \mathrm{~A}}$ receptor-deficient mice compared with wild-type littermates [44, 45]. It is now known that this occurs at least in part by a reduction in the expression of the antiangiogenic matrix protein thrombospondin-1 and increased macrophage production of vascular endothelial growth factor $[46,47]$. Moreover, topical adenosine $\mathrm{A}_{2 \mathrm{~A}}$ receptor agonists stimulate recruitment of endothelial precursor cells from the bone marrow to injured sites [45].

\section{Mast cells}

Adenosine is known to be a stimulus for mast cell degranulation. It has been demonstrated that this may occur through $\mathrm{A}_{3}$ receptor ligation, though it is interesting to note that inosine can also bind to the $A_{3}$ receptor and cause degranulation of the mast cell [48, 49]. Since mast cell degranulation is generally thought of as a potent proinflammatory signal, it is difficult to reconcile this seemingly untoward physiological function with the overall antiinflammatory nature of adenosine release. One possible explanation is that the release of histamines contained within the granules is a stimulus for suppression of the production of tumor necrosis factor- $\alpha$ and interleukin-12 while enhancing the release of the anti-inflammatory interleukin-10, at least in a murine model of endotoxemia [50]. Furthermore, upregulation of Th2 cytokines in mast cells may affect the immune function of other cell types, since adenosine-activated mast cells induce the production of IgE by B lymphocytes, an effect mediated by the adenosine $A_{2 B}$ receptor [51].

\section{Methotrexate}

Treatment of rheumatoid arthritis took a great leap half a century ago with the discovery of the beneficial effects of corticosteroids on this disease, a discovery that was, indeed, crowned by the award of a Nobel prize. It was around this time that methotrexate came into clinical use. While long in use for the treatment of malignant diseases, the use of methotrexate in rheumatoid arthritis has only become widespread in the past 20 years [52-54]. Since then, it has been a mainstay of rheumatoid therapy, and its popularity, as well as its efficacy, in this disease has remained undisputed, even with the appearance of newer biological agents.

Methotrexate was originally developed as an anti-folate agent. As such, it has antiproliferative properties against immune cells active in the flaring rheumatoid synovium, such as the lymphocyte. This was indeed thought to be the principal mechanism of action of methotrexate in rheumatoid arthritis. Methotrexate induces clonal deletion of activated $\mathrm{T}$ lymphocytes in mixed lymphocyte reactions, and this effect holds true for peripheral blood lymphocytes taken from patients with rheumatoid arthritis [55]. However, the effect is short-lived, making it difficult to explain why administration of methotrexate in a dose frequency of only once a week, as is normally the case in rheumatoid arthritis treatment, could result in clinical immunosuppression from its lymphocyte antiproliferative properties alone.

Other theories have existed to explain the anti-inflammatory actions of methotrexate. Since methotrexate is an inhibitor of dihydrofolate reductase, it suppresses tetrahydrofolate synthesis. Tetrahydrofolate is a methyl group donor that enables the formation of methionine from homocysteine. A metabolite of methionine, $S$-adenosyl- 
methionine, is also a methyl donor in the formation of the polyamines spermine and spermidine. These polyamines are processed by immune cells, including monocytes, resulting in toxic metabolites. Thus, methotrexate can inhibit the formation of detrimental polyamines. It has been shown that methotrexate can inhibit the generation of spermine and spermidine in stimulated rheumatoid lymphocytes [56]. Inhibitors of polyamine production increased interleukin-2 production by peripheral blood mononuclear cells from rheumatoid arthritis patients, suggesting that polyamines may be associated with diminution of $\mathrm{T}$ cell effector function [57]. Urinary polyamine levels are increased in patients with rheumatoid arthritis and may be associated with disease activity [58]. These effects are, however, reversed by folic acid, and are therefore insufficient to explain the anti-inflammatory effects of low-dose methotrexate that are unaffected by folic acid administration.

In the molecular pathways leading to the de novo synthesis of purines, accumulation of various intermediates can lead to the release of adenosine [59]. Methotrexate can be thought of as a prodrug. Once ingested, it is taken up by cells via the reduced folate carrier and, in turn, polyglutamated [60]. These polyglutamates, which remain in cells for time periods measured in weeks, are potent inhibitors of one of the key enzymes involved in the de novo biosynthesis of purines, aminoimidazole-carboxy-amidoadenosine ribonucleotide (AICAR) transformylase [6163]. This enzyme inhibition effect occurs at pharmacologically relevant concentrations of methotrexate and can readily explain the clinically persistent anti-inflammatory effect of the infrequent once-a-week dosing interval. Thus, it is likely that the principal mechanism of action of lowdose methotrexate as used in inflammatory joint diseases such as rheumatoid arthritis is different from its cellular effects as a chemotherapeutic agent. Urinary excretion of aminoimidazole carboxamide was increased following methotrexate administration in a rat adjuvant arthritis model [64]. Inhibition of AICAR transformylase leads to an increase in its substrate, AICAR. The accumulation of AICAR, in turn, has important effects on key enzymes that influence adenine nucleotide metabolism. AICAR itself is an inhibitor of AMP deaminase, which converts AMP to inosine monophosphate. A metabolite of AICAR, aminoimidazole-carboxamido-ribonucleoside (AICAside), inhibits adenosine deaminase. The net effect of AICAR accumulation, therefore, is a rise in intracellular AMP and adenosine levels, an effect known to occur with methotrexate in pharmacological concentrations in animal models $[14,65]$.

These AMP and adenosine elevating effects of methotrexate are supported by various lines of evidence in vivo. The development of adjuvant arthritis in the rat was suppressed by direct infusion of adenosine into the knee [66]. 8-Phenyl theophylline, a non-selective adenosine receptor antagonist, exacerbated leukotriene $\mathrm{B}_{4}$-mediated inflammatory responses in a hamster cheek pouch model of inflammation, suggesting that adenosine itself plays an antiinflammatory role [67]. Szabo et al. reported that an adenosine $\mathrm{A}_{3}$ receptor agonist, N6-(3-iodobenzyl)-adenosine-5'- $N$-methyl-uronamide (IB-MECA), reduced the severity of joint inflammation in a collagen-induced model of arthritis. This was accompanied by a reduction in neutrophil infiltration and suppression of macrophage inflammatory protein (MIP)-1 $\alpha$ production in the paws of the animals [68].

We first reported that weekly treatment with methotrexate increased splenocyte AICAR concentrations and also increased adenosine levels in inflammatory exudates [14]. Blockade of adenosine receptors reversed the anti-inflammatory effects of methotrexate. Similarly, Montesinos et al. showed that weekly doses of methotrexate increased adenosine levels in the exudates of inflamed murine air pouches, which was associated with a decrease in leukocyte accumulation and tumor necrosis factor- $\alpha$ production, effects not seen in adenosine $A_{2 A}$ or $A_{3}$ receptor-deficient mice [69]. The non-selective adenosine receptor antagonists, theophylline and caffeine, both reversed the beneficial effects of methotrexate in a rat adjuvant arthritis model of rheumatoid arthritis, as evidenced by disease severity index, hindpaw swelling, and hindpaw ankylosis [70].

Interestingly, the observation that caffeine reverses the anti-inflammatory effects of methotrexate has also been noted in humans. Silke et al. first reported that coffee ingestion was associated with poor clinical response to methotrexate, and patients with high caffeine intake were more likely to discontinue methotrexate treatment, presumably because of lack of response [71]. Coffee itself has been reported to have been directly correlated with rheumatoid factor positivity, and consumption of more than four cups of coffee a day was associated with a greater risk of developing frank rheumatoid factor-positive rheumatoid arthritis [72]. Nesher et al. have confirmed the reduction in efficacy of methotrexate treatment by caffeine consumption in patients with rheumatoid arthritis [73]. Recently, Ralph and colleagues reported that reduction in synovial expression of the orphan nuclear receptor NURR1 is the first change observed in patients treated with methotrexate and that the effects of methotrexate on NURR1 are mediated by adenosine acting at $\mathrm{A}_{2 \mathrm{~A}}$ receptors [74].

Although we have focused our discussion on methotrexate, other anti-rheumatic and immuno-modulatory agents have also been shown to exert their anti-inflammatory effects in an adenosine-dependent manner. Most important among these are sulfasalazine [75, 76], FK506 [77] and aspirin [78, 79]. 


\section{Conclusion}

The role of adenosine in the modulation of inflammation has been appreciated only in recent years, yet this Cinderella of the inflammatory response has a clear influence on many cell types that govern the pathogenesis of inflammatory rheumatic diseases. The role of cytokines in the mediation of rheumatic joint damage has been exploited in recent anti-rheumatic drug development. Adenosine also has a part to play in modulating the generation of cytokines relevant to the development of rheumatic diseases. The overall effects of adenosine, often beneficial in rheumatic disease, are exemplified by its involvement in commonly used anti-rheumatic drug treatments. Adenosine analogs may one day find their way into the clinic.

Acknowledgments This work was supported by grants from the Scleroderma Foundation, Spanish Ministry of Education, National Institutes of Health (AA13336, AR41911, GM56268, DK56621), King Pharmaceuticals, the General Clinical Research Center (M01RR00096) and by the Kaplan Cancer Center of New York University School of Medicine.

\section{References}

1. Resta R, Thompson LF (1997) SCID: the role of adenosine deaminase deficiency. Immunol Today 18(8):371-374

2. Blackburn MR, Kellems RE (2005) Adenosine deaminase deficiency: metabolic basis of immune deficiency and pulmonary inflammation. Adv Immunol 86:1-41

3. Thompson LF, Vaughn JG, Laurent AB, Blackburn MR, Van De Wiele CJ (2003) Mechanisms of apoptosis in developing thymocytes as revealed by adenosine deaminase-deficient fetal thymic organ cultures. Biochem Pharmacol 66(8):1595-1599

4. Cronstein BN, Kramer SB, Weissmann G, Hirschhorn R (1983) A new physiological function for adenosine: regulation of superoxide anion production. Trans Assoc Am Physicians 96:384-391

5. Cronstein BN, Kramer SB, Weissmann G, Hirschhorn R (1983) Adenosine: a physiological modulator of superoxide anion generation by human neutrophils. J Exp Med 158(4):1160-1177

6. Cronstein BN, Kramer SB, Rosenstein ED, Weissmann G, Hirschhorn R (1985) Adenosine modulates the generation of superoxide anion by stimulated human neutrophils via interaction with a specific cell surface receptor. Ann N Y Acad Sci 451:291301

7. Cronstein BN, Rosenstein ED, Kramer SB, Weissmann G, Hirschhorn R (1985) Adenosine: a physiologic modulator of superoxide anion generation by human neutrophils. Adenosine acts via an A2 receptor on human neutrophils. J Immunol 135 (2):1366-1371

8. Sullivan GW, Luong LS, Carper HT, Barnes RC, Mandell GL (1995) Methylxanthines with adenosine alter TNF alpha-primed PMN activation. Immunopharmacology 31(1):19-29

9. Khoa ND, Montesinos MC, Reiss AB, Delano D, Awadallah N, Cronstein BN (2001) Inflammatory cytokines regulate function and expression of adenosine $\mathrm{A}(2 \mathrm{~A})$ receptors in human monocytic THP-1 cells. J Immunol 167(7):4026-4032

10. Khoa ND, Postow M, Danielsson J, Cronstein B (2006) Tumor necrosis factor-\{alpha $\}$ prevents desensitization of $\mathrm{G}\{$ alpha $\}$ s- coupled receptors by regulating GRK2 association with the plasma membrane. Mol Pharmacol 69(4):1311-1319

11. Nguyen DK, Montesinos MC, Williams AJ, Kelly M, Cronstein BN (2003) Th1 cytokines regulate adenosine receptors and their downstream signaling elements in human microvascular endothelial cells. J Immunol 171(8):3991-3998

12. Cronstein BN, Levin RI, Philips M, Hirschhorn R, Abramson SB, Weissmann G (1992) Neutrophil adherence to endothelium is enhanced via adenosine A1 receptors and inhibited via adenosine A2 receptors. J Immunol 148(7):2201-2206

13. Sullivan GW, Rieger JM, Scheld WM, Macdonald TL, Linden J (2001) Cyclic AMP-dependent inhibition of human neutrophil oxidative activity by substituted 2-propynylcyclohexyl adenosine $\mathrm{A}(2 \mathrm{~A})$ receptor agonists. Br J Pharmacol 132(5):10171026

14. Cronstein BN, Naime D, Ostad E (1993) The antiinflammatory mechanism of methotrexate: increased adenosine release at inflamed sites diminishes leukocyte accumulation in an in vivo model of inflammation. J Clin Invest 92:2675-2682

15. Firestein GS, Bullough DA, Erion MD, Jimenez R, RamirezWeinhouse M, Barankiewicz J et al (1995) Inhibition of neutrophil adhesion by adenosine and an adenosine kinase inhibitor. The role of selectins. J Immunol 154(1):326-334

16. Wollner A, Wollner S, Smith JB (1993) Acting via A2 receptors, adenosine inhibits the upregulation of Mac-1 (Cd11b/CD18) expression on FMLP-stimulated neutrophils. Am J Respir Cell Mol Biol 9(2):179-185

17. Cronstein BN, Haines KA, Kolasinski S, Reibman J (1992) Occupancy of $\mathrm{G}$ alpha s-linked receptors uncouples chemoattractant receptors from their stimulus-transduction mechanisms in the neutrophil. Blood 80(4):1052-1057

18. Sullivan GW, Lee DD, Ross WG, DiVietro JA, Lappas CM, Lawrence $\mathrm{MB}$ et al (2004) Activation of A2A adenosine receptors inhibits expression of alpha 4/beta 1 integrin (very late antigen-4) on stimulated human neutrophils. J Leukoc Biol 75(1):127-134

19. Wakai A, Wang JH, Winter DC, Street JT, O'Sullivan RG, Redmond HP (2001) Adenosine inhibits neutrophil vascular endothelial growth factor release and transendothelial migration via A2B receptor activation. Shock 15(4):297-301

20. Xaus J, Mirabet M, Lloberas J, Soler C, Lluis C, Franco R et al (1999) IFN-gamma up-regulates the A2B adenosine receptor expression in macrophages: a mechanism of macrophage deactivation. J Immunol 162(6):3607-3614

21. Hasko G, Szabo C, Nemeth ZH, Kvetan V, Pastores SM, Vizi ES (1996) Adenosine receptor agonists differentially regulate IL-10, TNF-alpha, and nitric oxide production in RAW 264.7 macrophages and in endotoxemic mice. J Immunol 157(10):4634-4640

22. Hasko G, Kuhel DG, Chen JF, Schwarzschild MA, Deitch EA, Mabley JG et al (2000) Adenosine inhibits IL-12 and TNF-[alpha] production via adenosine $\mathrm{A} 2 \mathrm{a}$ receptor-dependent and independent mechanisms. FASEB J 14(13):2065-2074

23. Hasko G, Nemeth ZH, Vizi ES, Salzman AL, Szabo C (1998) An agonist of adenosine A3 receptors decreases interleukin-12 and interferon-gamma production and prevents lethality in endotoxemic mice. Eur J Pharmacol 358(3):261-268

24. Link AA, Kino T, Worth JA, McGuire JL, Crane ML, Chrousos GP et al (2000) Ligand-activation of the adenosine A2a receptors inhibits IL-12 production by human monocytes. J Immunol 164 (1):436-442

25. Leonard EJ, Shenai A, Skeel A (1987) Dynamics of chemotactic peptide-induced superoxide generation by human monocytes. Inflammation 11(2):229-240

26. Merrill JT, Shen C, Schreibman D, Coffey D, Zakharenko O, Fisher R et al (1997) Adenosine A1 receptor promotion of multinucleated giant cell formation by human monocytes: a 
mechanism for methotrexate-induced nodulosis in rheumatoid arthritis. Arthritis Rheum 40(7):1308-1315

27. Panther E, Idzko M, Herouy Y, Rheinen H, Gebicke-Haerter PJ, Mrowietz $U$ et al (2001) Expression and function of adenosine receptors in human dendritic cells. FASEB J 15(11):1963-1970

28. Panther E, Corinti S, Idzko M, Herouy Y, Napp M, la Sala A et al (2003) Adenosine affects expression of membrane molecules, cytokine and chemokine release, and the T-cell stimulatory capacity of human dendritic cells. Blood 101(10):3985-3990

29. Huang S, Apasov S, Koshiba M, Sitkovsky M (1997) Role of A2a extracellular adenosine receptor-mediated signaling in adenosinemediated inhibition of T-cell activation and expansion. Blood 90 (4): $1600-1610$

30. Koshiba M, Kojima H, Huang S, Apasov S, Sitkovsky MV (1997) Memory of extracellular adenosine A2A purinergic receptormediated signaling in murine $\mathrm{T}$ cells. J Biol Chem 272 (41):25881-25889

31. Koshiba M, Rosin DL, Hayashi N, Linden J, Sitkovsky MV (1999) Patterns of A2A extracellular adenosine receptor expression in different functional subsets of human peripheral $\mathrm{T}$ cells. Flow cytometry studies with anti-A2A receptor monoclonal antibodies. Mol Pharmacol 55(3):614-624

32. Lappas CM, Rieger JM, Linden J (2005) A2A adenosine receptor induction inhibits IFN-gamma production in murine CD4+ T cells. J Immunol 174(2):1073-1080

33. Lennon PF, Taylor CT, Stahl GL, Colgan SP (1998) Neutrophilderived 5'-adenosine monophosphate promotes endothelial barrier function via CD73-mediated conversion to adenosine and endothelial A2B receptor activation. J Exp Med 188(8):1433-1443

34. Richard LF, Dahms TE, Webster RO (1998) Adenosine prevents permeability increase in oxidant-injured endothelial monolayers. Am J Physiol 274(1 Pt 2):H35-H42

35. Eltzschig HK, Ibla JC, Furuta GT, Leonard MO, Jacobson KA, Enjyoji K et al (2003) Coordinated adenine nucleotide phosphohydrolysis and nucleoside signaling in posthypoxic endothelium: role of ectonucleotidases and adenosine A2B receptors. J Exp Med 198(5):783-796

36. Harrington EO, Smeglin A, Newton J, Ballard G, Rounds S (2001) Protein tyrosine phosphatase-dependent proteolysis of focal adhesion complexes in endothelial cell apoptosis. Am J Physiol Lung Cell Mol Physiol 280(2):L342-L353

37. Bouma MG, van den Wildenberg FA, Buurman WA (1996) Adenosine inhibits cytokine release and expression of adhesion molecules by activated human endothelial cells. Am J Physiol 270 (2 Pt 1):C522-C529

38. Ethier MF, Chander V, Dobson JG Jr. (1993) Adenosine stimulates proliferation of human endothelial cells in culture. Am J Physiol 265(1 Pt 2):H131-H138

39. Afzal A, Shaw LC, Caballero S, Spoerri PE, Lewin AS, Zeng D et al (2003) Reduction in preretinal neovascularization by ribozymes that cleave the A2B adenosine receptor mRNA. Circ Res 93 (6):500-506

40. Grant MB, Tarnuzzer RW, Caballero S, Ozeck MJ, Davis MI, Spoerri PE et al (1999) Adenosine receptor activation induces vascular endothelial growth factor in human retinal endothelial cells. Circ Res 85(8):699-706

41. Feoktistov I, Goldstein AE, Ryzhov S, Zeng D, Belardinelli L, Voyno-Yasenetskaya $\mathrm{T}$ et al (2002) Differential expression of adenosine receptors in human endothelial cells: role of $\mathrm{A} 2 \mathrm{~B}$ receptors in angiogenic factor regulation. Circ Res 90(5):531-538

42. Feoktistov I, Ryzhov S, Zhong H, Goldstein AE, Matafonov A, Zeng D et al (2004) Hypoxia modulates adenosine receptors in human endothelial and smooth muscle cells toward an A2B angiogenic phenotype. Hypertension 44(5):649-654

43. Sexl V, Mancusi G, Holler C, Gloria-Maercker E, Schutz W, Freissmuth M (1997) Stimulation of the mitogen-activated protein kinase via the A2A-adenosine receptor in primary human endothelial cells. J Biol Chem 272(9):5792-5799

44. Montesinos MC, Desai A, Chen JF, Yee H, Schwarzschild MA, Fink JS et al (2002) Adenosine promotes wound healing and mediates angiogenesis in response to tissue injury via occupancy of A(2A) receptors. Am J Pathol 160(6):2009-2018

45. Montesinos MC, Shaw JP, Yee H, Shamamian P, Cronstein BN (2004) Adenosine $\mathrm{A}(2 \mathrm{~A})$ receptor activation promotes wound neovascularization by stimulating angiogenesis and vasculogenesis. Am J Pathol 164(6):1887-1892

46. Desai A, Victor-Vega C, Gadangi S, Montesinos MC, Chu CC, Cronstein BN (2005) Adenosine A2A receptor stimulation increases angiogenesis by down-regulating production of the antiangiogenic matrix protein thrombospondin 1. Mol Pharmacol 67(5):1406-1413

47. Leibovich SJ, Chen JF, Pinhal-Enfield G, Belem PC, Elson G, Rosania A et al (2002) Synergistic up-regulation of vascular endothelial growth factor expression in murine macrophages by adenosine $\mathrm{A}(2 \mathrm{~A})$ receptor agonists and endotoxin. Am J Pathol 160(6):2231-2244

48. Ramkumar V, Stiles GL, Beaven MA, Ali H (1993) The A3 adenosine receptor is the unique adenosine receptor which facilitates release of allergic mediators in mast cells. J Biol Chem 268(23): $16887-16890$

49. Jin X, Shepherd RK, Duling BR, Linden J (1997) Inosine binds to $\mathrm{A} 3$ adenosine receptors and stimulates mast cell degranulation. J Clin Invest 100(11):2849-2857

50. Smith SR, Denhardt G, Terminelli C (2002) A role for histamine in cytokine modulation by the adenosine $\mathrm{A}(3)$ receptor agonist, 2-Cl-IB-MECA. Eur J Pharmacol 457(1):57-69

51. Ryzhov S, Goldstein AE, Matafonov A, Zeng D, Biaggioni I, Feoktistov I (2004) Adenosine-activated mast cells induce $\operatorname{IgE}$ synthesis by B lymphocytes: an A2B-mediated process involving Th2 cytokines IL-4 and IL-13 with implications for asthma. J Immunol 172(12):7726-7733

52. Weinblatt ME, Coblyn JS, Fox DA, Fraser PA, Holdsworth DE, Glass DN et al (1985) Efficacy of low-dose methotrexate in rheumatoid arthritis. N Engl J Med 312(13):818-822

53. Alarcon GS (2000) Methotrexate use in rheumatoid arthritis. A clinician's perspective. Immunopharmacology 47(2-3):259-271

54. Williams HJ, Willkens RF, Samuelson CO, Jr, Alarcon GS, Guttadauria M, Yarboro C et al (1985) Comparison of low-dose oral pulse methotrexate and placebo in the treatment of rheumatoid arthritis. A controlled clinical trial. Arthritis Rheum 28(7):721730

55. Genestier L, Paillot R, Fournel S, Ferraro C, Miossec P, Revillard JP (1998) Immunosuppressive properties of methotrexate: apoptosis and clonal deletion of activated peripheral T cells. J Clin Invest 102(2):322-328

56. Nesher G, Osborn TG, Moore TL (1996) In vitro effects of methotrexate on polyamine levels in lymphocytes from rheumatoid arthritis patients. Clin Exp Rheumatol 14(4):395-399

57. Flescher E, Bowlin TL, Ballester A, Houk R, Talal N (1989) Increased polyamines may downregulate interleukin 2 production in rheumatoid arthritis. J Clin Invest 83(4):1356-1362

58. Furumitsu Y, Yukioka K, Kojima A, Yukioka M, Shichikawa K, Ochi T et al (1993) Levels of urinary polyamines in patients with rheumatoid arthritis. J Rheumatol 20(10):1661-1665

59. Chan ES, Cronstein BN (2002) Molecular action of methotrexate in inflammatory diseases. Arthritis Res 4(4):266-273

60. Chabner BA, Allegra CJ, Curt GA, Clendeninn NJ, Baram J, Koizumi $S$ et al (1985) Polyglutamation of methotrexate. Is methotrexate a prodrug? J Clin Invest 76:907-912

61. Baggott JE, Vaughn WH, Hudson BB (1986) Inhibition of 5aminoimidazole-4-carboxamide ribotide transformylase, adenosine deaminase and $5^{\prime}$-adenylate deaminase by polyglutamates 
of methotrexate and oxidized folates and by 5-aminoimidazole4-carboxamide riboside and ribotide. Biochem J 236:193-200

62. Allegra CJ, Drake JC, Jolivet J, Chabner BA (1985) Inhibition of phosphoribosylaminoimidazolecarboxamide transformylase by methotrexate and dihydrofolic acid polyglutamates. Proc Natl Acad Sci U S A 82:4881-4885

63. Allegra CJ, Hoang K, Yeh GC, Drake JC, Baram J (1987) Evidence for direct inhibition of de novo purine synthesis in human MCF-7 breast cells as a principal mode of metabolic inhibition by methotrexate. J Biol Chem 262:13520-13526

64. Baggott JE, Morgan SL, Koopman WJ (1998) The effect of methotrexate and 7-hydroxymethotrexate on rat adjuvant arthritis and on urinary aminoimidazole carboxamide excretion. Arthritis Rheum 41(8): 1407-1410

65. Gruber HE, Hoffer ME, McAllister DR, Laikind PK, Lane TA, Schmid-Schoenbein GW et al (1989) Increased adenosine concentration in blood from ischemic myocardium by AICA riboside. Effects on flow, granulocytes, and injury. Circulation 80(5):1400 1411

66. Green PG, Basbaum AI, Helms C, Levine JD (1991) Purinergic regulation of bradykinin-induced plasma extravasation and adjuvant-induced arthritis in the rat. Proc Natl Acad Sci U S A 88:4162-4165

67. Rosengren S, Arfors KE, Proctor KG (1991) Potentiation of leukotriene B4-mediated inflammatory response by the adenosine antagonist, 8-phenyl theophylline. Int J Microcirc Clin Exp $10: 345-357$

68. Szabo C, Scott GS, Virag L, Egnaczyk G, Salzman AL, Shanley TP et al (1998) Suppression of macrophage inflammatory protein (MIP)-1alpha production and collagen-induced arthritis by adenosine receptor agonists. Br J Pharmacol 125(2):379-387

69. Montesinos MC, Desai A, Delano D, Chen JF, Fink JS, Jacobson MA et al (2003) Adenosine A2A or A3 receptors are required for inhibition of inflammation by methotrexate and its analog MX-68. Arthritis Rheum 48(1):240-247

70. Montesinos MC, Yap JS, Desai A, Posadas I, McCrary CT, Cronstein BN (2000) Reversal of the antiinflammatory effects of methotrexate by the nonselective adenosine receptor antagonists theophylline and caffeine: evidence that the antiinflammatory effects of methotrexate are mediated via multiple adenosine receptors in rat adjuvant arthritis. Arthritis Rheum 43(3):656663

71. Silke C, Murphy MS, Buckley T, Busteed S, Molloy MG, Phelan $M$ (2001) The effects of caffeine ingestion on the efficacy of methotrexate. Rheumatology (Oxford) 40[Suppl 1]:34

72. Heliovaara $M$, Aho $K$, Knekt $P$, Impivaara O, Reunanen A, Aromaa A (2000) Coffee consumption, rheumatoid factor, and the risk of rheumatoid arthritis. Ann Rheum Dis 59(8):631-635

73. Nesher G, Mates M, Zevin S (2003) Effect of caffeine consumption on efficacy of methotrexate in rheumatoid arthritis. Arthritis Rheum 48(2):571-572

74. Ralph JA, McEvoy AN, Kane D, Bresnihan B, FitzGerald O, Murphy EP (2005) Modulation of orphan nuclear receptor NURR1 expression by methotrexate in human inflammatory joint disease involves adenosine $\mathrm{A} 2 \mathrm{~A}$ receptor-mediated responses. J Immunol 175(1):555-565

75. Gadangi P, Longaker M, Naime D, Levin RI, Recht PA, Montesinos MC et al (1996) The anti-inflammatory mechanism of sulfasalazine is related to adenosine release at inflamed sites. J Immunol 156(5):1937-1941

76. Cronstein BN (1995) The antirheumatic agents sulphasalazine and methotrexate share an anti-inflammatory mechanism. Br J Rheumatol 34[Suppl 2]:30-32

77. Hwang KK, Hall CS, Spielman WS, Sparks HV (2001) FK506 promotes adenosine release from endothelial cells via inhibition of adenosine kinase. Eur J Pharmacol 425(2):85-93

78. Cronstein BN, Montesinos MC, Weissmann G (1999) Salicylates and sulfasalazine, but not glucocorticoids, inhibit leukocyte accumulation by an adenosine-dependent mechanism that is independent of inhibition of prostaglandin synthesis and p105 of NFkappaB. Proc Natl Acad Sci U S A 96(11):6377-6381

79. Cronstein BN, Montesinos MC, Weissmann G (1999) Sites of action for future therapy: an adenosine-dependent mechanism by which aspirin retains its antiinflammatory activity in cyclooxygenase-2 and NFkappaB knockout mice. Osteoarthritis Cartilage 7(4):361-363 